\title{
ROLE OF SCHOOL SUPPORT IN DEVELOPING ENGLISH WRITING SKILLS: A STUDY OF SECONDARY SCHOOLS IN PAKISTAN
}

\author{
Ali Furqan Syed, Ijaz Hussain, Saqib Sheraz and Shahnawaz Shahid \\ The University of Lahore Sargodha Campus \\ DOI: 10.46609/IJSSER.2021.v06i01.006 URL: https://doi.org/10.46609/IJSSER.2021.v06i01.006
}

\begin{abstract}
The purpose of this research was to explore the role of school support in developing English writing skills: A Study of Secondary Schools in Pakistan. In Pakistani schools, the teaching methodology based on the grammatical approach; the traditional grammar-translation method focused on the rote-memorization of grammatical patterns and structures. It had been narrated that through school support writing skills could be improved. School support plays important role in developing writing skills. In the same context, it was stated that there was a dire need to improve the writing skills among Pakistani students and for this purpose the said support might be useful to achieve the desired objectives for improving the creative writing skills. For this study survey design with a structured questionnaire was used. The data was obtained from the sampling population consisting of 7 secondary schools ( 5 public and 2 private) of district Lahore. A sample of the size 646 (73 teachers and 573 students, males and females) was selected by multi-stage random sampling. The data was analyzed by SPSS. The study results would have wide implications for classroom teachers, school heads, teacher trainers, and syllabus designers.
\end{abstract}

Keywords: School support, writing skills, grammar-translation method, rote-memorization, grammatical patterns.

\section{Introduction}

This study was designed to know the present state of writing skills (academic/ creative) in Pakistani secondary schools. Signs and symbols had been used for writing since pre-historic times. Each sign or symbol signified different concepts. Only powerful and prestigious people were allowed to learn the art of writing. In the educational context, some exams and tests are conducted to assess the writing skills of the students. They are given grades based on writing proficiency. The importance of writing can be judged by the fact that spoken words are temporary and transitory while writing is permanent, fixed, and unchangeable; spoken words are not saved, fly away into the air, the moment one speaks. Written text has readers not only in the present but in the future as well and can be retrieved whenever required. 


\section{International Journal of Social Science and Economic Research}

ISSN: $2455-8834$

Volume:06, Issue:01 "January 2021"

Writing produced with imaginative use is called creative writing. For generating new ideas mind is applied. The process of generating new ideas for speaking and writing is invariably the same. The words we speak are planned and sketched in our minds, and when those words come on paper by our hands they become writing. That is to say, the storehouse of both the skills is our mind which is teemed with uncountable ideas and thoughts and can be innovative and imaginative" (Sami Ulla, 2013).

Many students in Pakistan are unable to write creatively because most of them depend on cramming and ready-made material and do not bother to use their thinking ability. Teachers do not teach them the art of creative writing this is due to the unprofessional method of teaching on the part of the teacher who still relies on the indirect method of teaching English that is why they translate into Urdu.

In most Pakistani schools, institutional support in this regard is not adequately provided. The schools are forced to imply single teacher to teach almost all subjects. She/he may be expert and competent to teach Islamiat and Pakistan Studies but when comes to English, tries to use the same method and techniques, that are quite unsuitable. Teachers teach English as a subject rather than as a language; that results in the inability of students to learn English by proper method. In addition to this, to enhance the writing skills of the students, the schools are unable to provide state of the art facilities like multimedia, audio-visual aids, computers, libraries, and e-lab, etc. Many heads of the schools do not pay proper attention to the English writing skills of the students? The syllabus recommended by the school authorities does not give appropriate weight age to rote learning, instead In most schools, proper creative activities are being affected due to the continuous use of readymade materials (Siddiqui, 2007). The assessment procedures are also the reasons for the promotion and encouragement of rote learning. In this way, students can get good marks but they do not develop the habit of writing; the assessment procedures can play a vital role in the development of writing skills if some items are included in the tests related to writing creatively. The teachers should impart the importance of such exams and that would be advantageous for the learners.

In this context, Harmer (2004) stated that the teacher's role should be to prepare the learners for writing in the exams as it plays an important role in deciding what should go on in the classroom, and how teachers teach and learners learn and all this can have an impact on teaching and learning. In this way, in Pakistan, this practice can improve the writing practices if teachers give importance to the habit of writing creatively.

Rehman (2007) said that the performance of the learners is better on cramming based subjects but they show poor performance in comprehension and understating of the concepts. Additionally, concepts as given in the textbooks hardly match the cognitive level of the children. 


\section{International Journal of Social Science and Economic Research}

ISSN: $2455-8834$

Volume:06, Issue:01 "January 2021"

Our present system of examination is based on the final evaluation of how much the students have knowledge rather than the application of that knowledge. It shows that learners are unable to apply their cognitive skills rather; they just reproduce what they have learned by rote.

According to Imtiaz (2009) not only a lengthy and complex `syllabus designed by the higher authorities but also the non-cooperative attitude on part of the school administrations prove a big stumbling block in the way of learning writing skills. The pressure from the school management forces teachers to complete the given syllabus within the stipulated time that debars them to give time for the improvement of the writing skills of the students.

\section{Literature Review}

According to Peters (1986) writing defined as a "curiously solitary form of communication addressed to an absent and unknown reader." Abu-Ghararah (1998) defines writing as "logical organization and arrangement of the written sentences within a paragraph and paragraphs with the units of discourse and expression of the ideas." Grami (2010) defined writing as "a complicated cognitive work due to the reason that it demands careful thought, discipline, and concentration and it is not just a simple direct outcome of what the brain knows or can do at a specific time." The above-mentioned definitions of writing suggest that is known as a secondary activity that involves a difficult cognitive process that makes it a complex skill to teach and learn.

According to the social constructivist approach, writing is always closely related to the context. Based on context, specific constraints are managed on what should be written and how the idea can be expressed in a better way. According to Dudley-Evans \& St John's (2000) 'Dedicated and hard-working teaching staff is required for teaching writing to students and professionals who study English for specific purposes.”Serafini, E. J. (2017), Lake, J. B. (2019), \& Long, M. H. (2015) stated that it is the responsibility of the teacher to know the particular needs of ESP (English for Specific Purpose) student in writing and to pay attention to their academic or job requirements regarding this skill. By identifying the needs of the students, the teacher will be aware of the materials that he or she should use in class. He will also be able to orient the writing task towards their level of language, knowledge, and proficiency.

English writing is known as one of the best skills among the four fundamental skills in English learning and writing competence and this is too much indebted to the student's CTS (critical thinking skill). The traditional writing theories on English writing stress upon the same pattern of composition. But teachers urge the students to learn only set pattern composition and sentences, ignoring the spirits of student's CTS during the writing process. As a result, students are unable to write a quality composition and put forward creative ideas. In short, there are three main problems faced by the teachers while teaching English writing at the secondary level in Pakistan: 


\section{International Journal of Social Science and Economic Research}

ISSN: $2455-8834$

Volume:06, Issue:01 "January 2021"

First, for a long time, in Pakistan English writing teaching puts stress only on the training of textual language skills. This type of training consists of analysis and imitation of structure such as vocabulary, syntax, and grammar of words, and does not bother about the implementation of CTS. Second, most of the learners think that correct use of grammar, attractive vocabulary and beautiful sentence structure are considered as the standard of excellent writing and they ignore the inner-thinking and profound logic of the content of the writing. Third, secondary school learners are devoid of logical thinking abilities such as comparison, analysis, abstraction, generalization, and formulation as well as CTS. CTS (Theory Model) can be further divided into two domains. These are known as cognitive skills and critical thinking skills.

Cognitive skills attribute to planning, examining, regulating, and evaluating critical thinking. The second type stresses the skills and standards, related to cognition and critical thinking temperament. The CTS model is very particular for measuring secondary school student's CTS due to its clear level and correct rating criterion.

Academic writing is considered an important skill that is needed in higher education, learning for academic communication, academic performance, academic achievement, and success. Anyhow, in an EFL context, most of the studies represented that a larger number of students have to bear hardships and difficulties in learning academic writing skills. It is thought that the problems of writing skills that learners faced at the university level seem to have a relation with the specific shortfall in the process of preparation at the secondary school in the context of curriculum and teaching.

English is considered a global language (Jung \& Norton, 2002, Mc Kay 2002). Crystal (2003)believed that English is considered as the international language used for a communicative purpose. Particularly, writing skills are necessary for getting success in higher educational learning (Ahmed, 2010), in work (Kellogg \&Raulerson, 2007: Prior, 2012).

Stoynoff (1997);Kellogg,\&Raulerson (2007) whispered that writing skills are essential for academic performance as well as functioning successfully at the workplace.

Hasballah (2010) assumed that in the education system, writing is a source through which learners can communicate and converse professionally with the higher authorities as well as teachers and the noblemen, who are providing teaching and learning activities. Jones (1995) says that writing is important because of its wide use in education and writing skills so that they are capable of doing daily work, make a conclusion as well as written papers and reports and complicated informational texts.

Among all the English Language skills, Writing is the most important (Hasballah, 2010). Yet it is a complex skill (Gabrielatos,2000) for those in the process of picking up a language. Writing is 
International Journal of Social Science and Economic Research

ISSN: 2455-8834

Volume:06, Issue:01 "January 2021"

considered a difficult language skill that can be learned through an instructional process (Myles, 2002).

Byrne (1979) points out that there is a need for learning formal writing, and sets of drills in a formal way of instructional settings. It is also essential to have a command of the written communication, construction of specific language format and then one should know the arrangement and concepts in a specific way so that the ideas may be comprehended by a reader. Richard and Nunan (1990) suggested that the methodology adopted by the students of English as a foreign language (EFL) is considered a difficult task because it is a part of a lengthy language learning process. In the opinion of Richards and Renandya (2002), the difficulties found in writing skills are in:

a. Using proper words needs to be used for a specific creation and arrangement of concepts.

b. Understandable tests can be prepared by using such ideas.

Nunan (2003) said that creating a persuasive piece of writing is an effort for all English learners including those who speak English as their mother tongue.

\section{Statement of the Research Problem}

It has been noted that school support is rare in Pakistani schools for the improvement of writing skills whereas it helps to enhance the said skills significantly. This study intended to explain the effect of school support for the development of writing skills among high school grades.

\section{Research Questions}

What are the effects of school support on writing skills among secondary school students?

- Is there any significant difference of opinions of teachers and students on the role of school support in English writing skills?

- Is there any significant difference inthe opinions of government and private sector participants on the role of school support?

- Is there any significant difference of opinion of rural and urban students on the role of school support in writing skills?

- Is there any significant difference of opinion of male teachers and female teachers on the role of school support in writing skills?

- Is there any significant difference of opinions of male students and female students on the role of school support in writing skills?

\section{Methodology}

Using survey methodology with positivist paradigm as an organizational framework for the present study, the research method, research approach and the source of data were decided. 


\section{International Journal of Social Science and Economic Research}

ISSN: $2455-8834$

Volume:06, Issue:01 "January 2021"

Now, as the type of data involved in the study was quantitative, so quantitative approach was selected. Students and teachers of secondary schools were the sources of data collected for this study. It means that the unit of analysis was individuals not schools. The data source and data collection method are used in detail in the remaining part of the chapter.

All the private and public sector secondary schools of rural and urban areas of Lahore district were the target population of the study. But the reachable population of the study was the secondary schools that showed a willingness to take part in the research and where participants were available at the time of the study. From the accessible population consisting of five government and two private secondary schools, located in the Lahore district, two independent samples, one of the teachers and one of the students of the secondary level were selected by purposeful sampling.

The size of the teachers' sample was 73 and that of the students was 573. The sampling ratio for teachers was $11.3 \%$ and for students, it was $88.7 \%$.

For collecting data on research questions from the two independent samples, one questionnaire was designed. Moreover, items in the questionnaire had five response categories from strongly agree to strongly disagree having number labels from 1 to 5.

For reliability before data collection, piloting was done and after data collection, Cronbach's alpha was also applied after data entering and cleaning. The alpha value of the questionnaire was $.86($ cut off value $=$ over.70)

For content validity, care was taken that the instruments should be based on theories related to the concept being measured as suggested. Face validity is the judgment of the respondents and the experts that the instrument looks valid.

\section{Results}

The filled-in questionnaire was coded and entered into the computer for analysis with SPSS (version 20.0). The results of the analysis are given in the tables below:

Table 1

School Support Effects Writing Skills in English. $(N=646)$

\begin{tabular}{cllllllll}
\hline No. & Statements & SDA & DA & UD & A & SA & Mean & SD \\
\hline 1 & $\begin{array}{l}\text { School Support helps to learn writing } \\
\text { skills in English. }\end{array}$ & 38 & 42 & 28 & 239 & 299 & 4.11 & 1.13 \\
5 & $\begin{array}{l}\text { Availability of English teacher } \\
\text { supports to improve writing skills. }\end{array}$ & 29 & 30 & 41 & 198 & 348 & 4.25 & 1.06 \\
\hline
\end{tabular}


International Journal of Social Science and Economic Research

ISSN: 2455-8834

Volume:06, Issue:01 "January 2021"

\begin{tabular}{|c|c|c|c|c|c|c|c|c|}
\hline 8 & $\begin{array}{l}\text { Qualification of the teacher helps in } \\
\text { learning writing skills. }\end{array}$ & 22 & 28 & 50 & 217 & 329 & 4.24 & 1.00 \\
\hline 17 & $\begin{array}{l}\text { Trained teachers help in learning } \\
\text { writing skills. }\end{array}$ & 17 & 21 & 51 & 261 & 296 & 4.24 & 0.92 \\
\hline 22 & $\begin{array}{l}\text { If teachers provide proper guidance } \\
\text { for ambition achievement to the } \\
\text { students, it also enhances writing } \\
\text { skills. }\end{array}$ & 21 & 26 & 56 & 277 & 266 & 4.15 & 0.97 \\
\hline 25 & $\begin{array}{l}\text { If the school is well aware of the } \\
\text { students ambitions, it increases } \\
\text { writing skills. }\end{array}$ & 28 & 50 & 78 & 300 & 190 & 3.89 & 1.05 \\
\hline 26 & $\begin{array}{l}\text { If school supports the students for } \\
\text { ambition achievement, it improves } \\
\text { writing skills. }\end{array}$ & 27 & 32 & 92 & 257 & 238 & 4.00 & 1.04 \\
\hline
\end{tabular}

Table 2

Comparison of Teachers and Students on the Role of School Support in Writing Skills

\begin{tabular}{|c|c|c|c|c|c|c|}
\hline \multirow[t]{2}{*}{ Factors } & \multicolumn{2}{|c|}{ Teacher } & \multicolumn{2}{|c|}{ Students } & \multicolumn{2}{|l|}{ t-test } \\
\hline & $\mathrm{M}$ & SD & $\mathrm{M}$ & SD & $\mathrm{t}$ & $\mathrm{P}$ \\
\hline 1. Logical thinking & 4.13 & 0.50 & 4.04 & 0.66 & 1.03 & 0.303 \\
\hline 2. Proper feedback & 4.27 & 0.42 & 4.13 & 0.67 & 1.73 & 0.084 \\
\hline 3. School Support & 4.23 & 0.43 & 4.11 & 0.59 & 1.62 & 0.106 \\
\hline 4. Communicative activities & 4.08 & 0.56 & 3.83 & 0.76 & 2.71 & $<0.007$ \\
\hline 5. Assessment procedure & 3.90 & 0.52 & 3.83 & 0.77 & 0.80 & 0.425 \\
\hline 6. Incentives help & 4.21 & 0.59 & 4.09 & 0.80 & 1.19 & 0.235 \\
\hline 7. Effective teaching methodology & 4.09 & 0.64 & 3.90 & 0.83 & 1.91 & 0.057 \\
\hline
\end{tabular}

Table 3

Comparison of Government and Private Participants on the Role of School Support in Writing Skills

\begin{tabular}{|c|c|c|c|c|c|c|}
\hline \multirow[t]{2}{*}{ Factors } & \multicolumn{2}{|c|}{ Government } & \multicolumn{2}{|c|}{ Private } & \multicolumn{2}{|c|}{ t-test } \\
\hline & M & SD & M & SD & $\mathrm{t}$ & $\mathrm{P}$ \\
\hline 1. Logical thinking & 4.02 & 0.65 & 4.11 & 0.61 & 1.78 & 0.075 \\
\hline 2. Proper feedback & 4.12 & 0.66 & 4.19 & 0.62 & 1.30 & 0.193 \\
\hline
\end{tabular}


International Journal of Social Science and Economic Research

ISSN: 2455-8834

Volume:06, Issue:01 "January 2021"

\begin{tabular}{lllllll}
\hline 3. School Support & 4.10 & 0.61 & 4.17 & 0.50 & 1.53 & 0.127 \\
4. Communicative activities & 3.78 & 0.74 & 4.00 & 0.73 & 3.62 & $<0.000$ \\
5. Examination system & 3.90 & 0.72 & 3.71 & 0.77 & 3.13 & $<0.002$ \\
6. Incentives help & 4.09 & 0.75 & 4.14 & 0.82 & 0.76 & 0.450 \\
7. Effective & & & & & & \\
methodology teaching & 3.89 & 0.84 & 3.98 & 0.76 & 1.38 & 0.167 \\
\hline
\end{tabular}

Table 4

Comparison of Rural and Urban Students on the Role of School Support in Writing Skills

\begin{tabular}{|c|c|c|c|c|c|c|}
\hline \multirow[t]{3}{*}{ Factors } & \multicolumn{2}{|c|}{$\begin{array}{c}\text { Rural } \\
\text { students }\end{array}$} & \multicolumn{2}{|c|}{$\begin{array}{l}\text { Urban } \\
\text { students }\end{array}$} & \multicolumn{2}{|c|}{ t-test } \\
\hline & \multicolumn{2}{|c|}{$\mathrm{M}$} & $\mathrm{M}$ & & $\mathrm{t}$ & $\mathrm{P}$ \\
\hline & & SD & & SD & & \\
\hline 1. Logical thinking & 3.75 & 0.75 & 4.16 & 0.57 & 7.05 & $<0.001$ \\
\hline 2. Proper feedback & 3.84 & 0.71 & 4.24 & 0.62 & 6.71 & $<0.001$ \\
\hline 3. School Support & 3.80 & 0.61 & 4.23 & 0.53 & 8.44 & $<0.001$ \\
\hline 4. Communicative activities & 3.53 & 0.82 & 3.95 & 0.71 & 6.09 & $<0.001$ \\
\hline 5. Assessment procedure & 3.73 & 0.72 & 3.86 & 0.79 & 1.83 & 0.068 \\
\hline 6. Incentives help & 3.92 & 0.73 & 4.16 & 0.81 & 3.20 & $<0.001$ \\
\hline 7. Effective teaching methodology & 3.63 & 0.95 & 4.00 & 0.75 & 4.88 & $<.001$ \\
\hline
\end{tabular}

\section{Table 5}

Comparison of Male Teachers and Female Teachers on the Role of School Support in Writing Skills

\begin{tabular}{|c|c|c|c|c|c|c|}
\hline \multirow[t]{2}{*}{ Factors } & \multicolumn{2}{|c|}{$\begin{array}{l}\text { Male } \\
\text { Teachers }\end{array}$} & \multicolumn{2}{|c|}{$\begin{array}{l}\text { Female } \\
\text { Teachers }\end{array}$} & \multicolumn{2}{|c|}{$\mathrm{t}$-test } \\
\hline & $\mathrm{M}$ & SD & $\mathrm{M}$ & SD & $\mathrm{T}$ & $P$ \\
\hline 1. Logical thinking & 4.50 & 0.20 & 4.10 & 0.50 & 1.77 & 0.081 \\
\hline 2. Proper feedback & 4.52 & 0.39 & 4.25 & 0.42 & 1.41 & 0.163 \\
\hline 3. School Support & 4.57 & 0.17 & 4.20 & 0.43 & 1.89 & 0.063 \\
\hline 4. Communicative activities & 4.48 & 0.39 & 4.05 & 0.57 & 1.67 & 0.100 \\
\hline 5. Assessment procedure & 4.35 & 0.22 & 3.87 & 0.52 & 2.03 & $<0.046$ \\
\hline 6. Incentives help & 4.80 & 0.18 & 4.16 & 0.59 & 2.39 & $<0.019$ \\
\hline Effective & 4.47 & 0.38 & 4.06 & 0.65 & 1.36 & 0.177 \\
\hline
\end{tabular}


International Journal of Social Science and Economic Research

ISSN: 2455-8834

Volume:06, Issue:01 "January 2021"

methodology

Table 6

Comparison of Male Students and Female Students on the Role of School Support in Writing Skills

\begin{tabular}{|c|c|c|c|c|c|c|c|}
\hline \multirow[t]{2}{*}{ Factors } & \multicolumn{2}{|c|}{$\begin{array}{l}\text { Male } \\
\text { Students }\end{array}$} & & \multicolumn{2}{|c|}{$\begin{array}{l}\text { Female } \\
\text { Students }\end{array}$} & \multicolumn{2}{|c|}{ t-test } \\
\hline & $\mathrm{M}$ & SD & & $\mathrm{M}$ & SD & $\mathrm{T}$ & $\mathrm{P}$ \\
\hline 1. Logical thinking & 4.06 & 0.59 & 4.00 & 0.78 & 4.06 & 1.02 & 0.31 \\
\hline 2. Proper feedback & 4.16 & 0.62 & 4.05 & 0.76 & 4.16 & 1.85 & 0.06 \\
\hline 3. School Support & 4.09 & 0.62 & 4.16 & 0.50 & 4.09 & $\begin{array}{l}- \\
1.32\end{array}$ & 0.19 \\
\hline 4. Communicative activities & 3.76 & 0.78 & 3.99 & 0.71 & 3.76 & - & $<.001$ \\
\hline 5. Assessment procedure & 3.87 & 0.78 & 3.72 & 0.73 & 3.87 & 2.17 & $<0.03$ \\
\hline 6. Incentives help & 4.10 & 0.81 & 4.07 & 0.77 & 4.10 & 0.39 & 0.70 \\
\hline $\begin{array}{l}\text { 7. Effective teaching } \\
\text { methodology }\end{array}$ & 3.94 & 0.80 & 3.82 & 0.88 & 3.94 & 1.62 & 0.10 \\
\hline
\end{tabular}

\section{DISCUSSION}

\section{Research Questions:}

What are the effects of school support on writing skills among secondary school students?

The results presented in table 1 indicate that the participants tend to agree that school support helps the students on writing skills among secondary school students. These results of this study are similar to many other researchers (e.g., Larsen- Freeman, 2000, Harmer, 2001).

- Is there any significant difference of opinions of teachers and students on the role of school support in English writing skills?

To answer this question t-test was run to test the significance of difference and a p-value (0.05) was obtained, the results of the test in table fifteen show that there is a significant difference in opinion of students and teachers on factor 'communicative activities' and other factors opinions of students and teachers are same.

- Is there any significant difference inthe opinions of private and public sector students and teachers on the role of school support? 


\section{International Journal of Social Science and Economic Research}

ISSN: $2455-8834$

Volume:06, Issue:01 "January 2021"

To answer this question t-test was applied to test the significance of difference and a pvalue (0.05) was obtained, the results of the test in table sixteen show that there is a significant difference in opinions of government and private sectors students and teachers on factors 'communicative activities' and 'assessment procedures' and in other factors opinions of students and teachers are alike.

- Is there any significant difference of opinion of rural and urban students on the role of school support in writing skills?

To show the answer to this question t-test was applied to test the significance of difference and a p-value (0.05) was obtained, the results of the test in table nineteen indicate that there is not a significant difference in opinions of rural and urban students on the factors 'assessment procedure' and on the other factors opinions of rural students and urban students are related.

- Is there any significant difference of opinion of male teachers and female teachers on the role of school support in writing skills?

To show the answer to this question t-test was applied to test the significance of difference and a p-value (0.05) was obtained, the results of the test in table twenty show that there is a significant difference in opinions of male and female teachers on the factors 'assessment procedure' and 'incentives help' and on other factors opinions of male and female teachers are same.

- Is there any significant difference of opinions of male students and female students on the role of school support in writing skills?

To show the answer to this question t-test was run to test the significance of difference and a p-value (0.05) was obtained, the results of the test in table twenty-one show that there is a significant difference in the opinions of male and female students on the factors 'communicative activities' and 'assessment procedure' and on the other factors opinions of male and female students are alike.

\section{Conclusions}

The participants tend to agree that school support helps the students on writing skills among secondary school students. There is a significant difference in opinions of government and private sectors students and teachers on factors 'communicative activities' and 'assessment procedures' and on other factors opinions of students and teachers are the same. There is a significant difference in opinions of male and female participants on factors 'communicative activities' and on other factors opinions of male and female students and teachers are the same. There is not a significant difference in opinions of rural and urban students on the factors 'assessment procedure' and on the other factors opinions of rural students and urban students are same. There is a significant difference in opinions of male and female teachers on the factors 'assessment procedure' and 'incentives help' and on other factors opinions of male and female 


\section{International Journal of Social Science and Economic Research}

ISSN: $2455-8834$

Volume:06, Issue:01 "January 2021"

teachers are the same. There is a significant difference in the opinions of male and female students on the factor 'communicative activities' and 'assessment procedure' and on the other factors opinions of male and female students are alike.

\section{Recommendations}

It is suggested that assessment procedures (classroom) should be linked with school support procedures which are based on individual counseling and guidance. It is recommended that communicative activities in English teaching classrooms should be in the target language. It is found that the logical thinking of secondary school students is encouraged by the teachers while teaching writing skills to the students. It also recommended that there should be proper feedback on the written test in English by the English teachers. This feedback would motivate the learners and their performance would be far better. English teachers must offer incentives to high performers in the English language class while teaching writing skills. These incentives would encourage performance better in learning writing skills. There is a need for that school should support the students by providing audiovisual aids and other helping materials. Students would learn writing skills quite easily with the cooperation of the school. It suggested that the methodology of teaching writing skills should be effective and efficient. New and novel methods should be devised by the English teachers while teaching writing skills.

\section{References}

Abu Ghararah, A. H. (1998). Teaching English as a foreign language: Procedures, techniques and activities. Tawbah Library, Riyadh.

Ahmed, A. H. (2010). Students' Problems with Cohesion and Coherence in EFL An introduction to the role of English as an internationallanguage and its implications for language teaching. OUP Oxford.and error analysis in student texts. TESL-EJ, 6, 1-20.

Byrne, R. W. (1979). Memory for urban geography. The Quarterly Journal of Experimental Psychology, 31(1), 147-154.

Crystal, D (2003). English as a Global Language.Cambridge University Press.

Dudley-Evans, T. (2000). Genre analysis: a key to a theory of ESP?.Ibérica, Revista de la AsociaciónEuropea de Lenguaspara Fines Específicos, (2), 3-11.

Grami, G. M. A. (2010). The Effects of Integrating Peer Feedback into University Level ESL Writing Curriculum: A Comparative Study in a Saudi Context.

Gabrielatos, C. (2000). EFL Writing: Product and Process (Part 3): A teaching framework. ELT News, 135, 26-27. 


\section{International Journal of Social Science and Economic Research}

ISSN: $2455-8834$

Volume:06, Issue:01 "January 2021"

Hasbollah, H. R. B. (2010). The writing performance of undergraduates at the University

Of Technology Mara, Terengganu, Malaysia. Journal of Languages and Culture, 1, 8-14.

Harmer, J. (2004).How to teach writing, Pearson Longman: New Delhi

Imtiaz, (2009).Quality issues in language teaching in higher education, in Mansoor, S, Sikandar,

A, Hussain, N, \&Ahsan N. M. (eds.) Emerging Issues in TEFL Challenges for Asia, Oxford: Oxford University Press. in composition. Educational Psychology Review. 8, 299325.In J.Tollefson(Ed.), Language Planning in Korea: The New Elementary English Program. Lawrence Erlbaum Associates, Inc.Publishers.

Jung, S., \& Norton, B. (2002).Language Policies in Education: Critical Issues.

Kellogg, R. T., \&Raulerson, B. A. (2007).Improving the writing skills of college students. Psychonomic bulletin \& review, 14(2), 237-242.

Klapper, J. (2003). Taking communication to the task? A critical review of recent trends in language teaching. Language Learning Journal, 27(1), 33-42.

Larsen-Freeman, D. (2001).Techniques and Principles in Language Teaching. Oxford: Oxford University Press

McKay, S. L. (2002). Teaching English as an international language: Rethinking goals and perspectives. $N Y$ : $O U P, 142-146$.

Myles, J. (2002). Second language writing and research: The writing process National Assessment of Educational Progress. (2002). The nation's report

Peters, P. (1986). Getting the theme across A study of dominant function in the academic writing of university students. Functional approaches to writing: Research perspectives, 169-185.

Richards, J. C., \&Nunan, D. (1990).Second language teacher education.Cambridge UniversityPress.

Richards, J. C., \&Renandya, W. A. (2002).Methodology in language teaching: A anthology of current practice. Cambridge University Press.http://dx.doi.org/10.1017/CBO9780511667190

Samiullah.M. (2013).Development of creative writing through a communicative approach at the secondary level.Unpublished Ph.D. Dissertation. 
International Journal of Social Science and Economic Research

ISSN: 2455-8834

Volume:06, Issue:01 "January 2021"

Stoynoff, S. (1997). Factors associated with international students' academic achievement.

Journal of Instructional Psychology, 24, 56-68

Serafini, E. J., Lake, J. B., \& Long, M. H. (2015).Needs analysis for specialized learner populations: Essential methodological improvements. English for Specific Purposes, 40, 11-26,

Siddiqui, S. (2007).Rethinking education in Pakistan: perceptions Sigma Press.AllamaIqbal Open University Islamabad 